\title{
The Effect of Inquiry Learning and Discovery Learning on Student Learning Achievement Viewed from Spatial Intelligence
}

\author{
Abdul Aziz, Budiyono, \& Sri Subanti \\ Faculty of Teaching and Education, Sebelas Maret University, Surakarta
}

\begin{abstract}
The goal of this study is to determine the effects of inquiry learning and discovery learning upon learning achievement of junior high school students viewed from spatial intelligence. The learning models compared were inquiry learning, discovery learning, and classical model. This study used a quasi-experimental approach with a $3 \times 3$ factorial design. The population was all students Grade 8 of junior high school in Solo. The sample used a stratified cluster random sampling strategy which consisted of 260 students, divided into three groups, namely: 86 students in experimental group 1,86 students in experimental group 2 , and 88 students in control group. The instruments used included a mathematics achievement test and a spatial intelligence test. The data analysis used the two-way multivariate analysis of variance. The results of this study are as follows: (1) inquiry learning and discovery learning gave better learning achievement than the classical model, while inquiry learning and discovery learning resulted the same learning achievement, (2) students with high spatial intelligence had similar learning achievement with those with middle spatial intelligence, and (3) students with high and middle spatial intelligence had better learning achievement than students who had low spatial intelligence.
\end{abstract}

Keywords: inquiry learning, discovery learning, spatial intelligence, learning achievement

\section{Introduction}

Civilization of a country will progress rapidly if its citizens can learn, understand, develop, and apply the rules of mathematical science in various aspects of life. Classic problems which still continue are the low mathematics achievement of students in elementary and secondary levels.

One of the cities in Indonesia where the students have low mathematics achievement is Solo (Surakarta). In the academic year 2013/2014, the performance of junior high school students in mathematics national examinations in the city was low, particularly in understanding the nature and elements of geometry and using them in problem solving. The performance of students in mastering this subject was $59.92 \%$ which is below the national average of $60.58 \%$. The students had low mathematics achievement especially in understanding geometry, they did not master the overall properties of plane geometry (flat side) and struggled with applications to construct problems. The students also performed poorly when dealing with geometry combined with the calculation of volume, area, and perimeter.

The low achievement of students' mathematics learning is influenced by many factors such as the too abstract and less attractive learning materials or teachers centered teaching methods where students tend to be passive and do not have the opportunity to think mathematically (Slameto, 2003). With these conditions, learning process is more focused on 
the results instead of directed towards the quality and the construction of meaning. The role of teachers and students should be evaluated on an ongoing basis to produce positive feedback.

In addition to learning achievement, learning process also includes communication activities. Hirschfield (2008) stated that communication is a fairly important part of mathematics and mathematics education (as cited in Dona, 2013). Students through communication can convey ideas and clarify understanding of what being studied. They can develop the ability to communicate and express themselves through written or verbal language and connect with mathematical matters. Thus, communication in mathematics is a way of delivering ideas via language, visual images, and mathematical symbols.

\section{Pedagogical Models}

Most models used by teachers in the learning process are still not optimal in improving the understanding or the potential of students and thus their mathematics achievement are still low. One of the success factors in improving learning achievement of students is to directly involve their contribution in teaching process through the use of appropriate learning models. Successful teachers are teachers who can implement learning models that match the characteristics of students.

If the retention rates of geometry material for students are still low, the learning models that may be suitable are based on constructivist theory. Constructivism is a learning process that helps explaining how the knowledge is constructed in the brain of the students (Ali Hamza $\&$ Muhlisrarini, 2014). Based on an understanding of constructivism, a teacher is unable to transfer knowledge directly to students in an exact form because they must build the knowledge based on their experiences and understanding. In other words, a learning experience can be effective and meaningful if in the process of teaching and learning students can construct some understanding that can be expressed.

\footnotetext{
The constructivists proposed several instructional strategies, among the cooperative learning, collaborative learning, problem based learning etc. are prominent. Therefore, to keep pace with the changing circumstances, we should not keep ourselves aloof from new experiments in the field of education to make learning more effective and enjoyable experience for pupils (Dheeraj \& Kumari, 2013. p. 1).
}

There are several constructivism learning models developed by experts and practitioners, including the discovery based learning model using cooperative groups of students. Through studies conducted by Wilcox (Slavin, 1977 in Hosnan, 2014) on learningbased discovery, students are able to actively participate and contribute to the learning process through experiments that have been conducted cooperatively so that they can be guided to discover principles and concepts and construct new knowledge within themselves. Students develop questions that they want to answer, research the topic using time in class, present what they have learned, and reflect on what and how they learned. Discovery learning is an inquiry- 
based constructivist learning theory that takes place in problem solving situations where the students draw their own past experience and existing knowledge to discover facts and relationships and new truths to be learned. It is supported by the work of learning theorists and psychologists Jean Piaget, Jerome Bruner, and Seymour Papert. In some formats, discovery learning is an unguided format involving trial and error.

Proponents of this theory claim that discovery learning: (1) encourages active engagement; (2) promotes motivation; (3) promotes ownership, responsibility, and independence; (4) develops creativity and problem solving skills; (5) and adjusts the learning experiences to students' needs and interests. However, some critics claim that discovery learning creates cognitive overload and may result in misconceptions and fuzzy logic which are difficult to detect by teachers.

Another discovery-based learning model that has been developed by educational experts is inquiry learning. Both these learning models have been proven to enhance the participation of students in the learning process, so that the learning achievement can be maximized.

The inquiry learning model (inquiry learning) emphasizes the process of seeking and finding. The role of the students in this method is to seek and find answers for themselves within the subject matter, while teachers act as facilitators and mentor students to guide along the process. Thus, inquiry learning starts by posing questions or problems rather than simply presenting established facts and the process is assisted by a facilitator. Inquiry learning is a series of learning activities that seek to emphasize critical thinking and analytical processes of seeking and finding an answer to the problem in question. Inquiry learning is a constructivist approach where the overall goal is for students to construct meaning. While teachers may guide the inquiry to various degrees (externally facilitated) and set considerations for a classroom inquiry, true inquiry is internally motivated. It is an umbrella term that incorporates many current learning approaches (including project based learning, design thinking) and may take various forms depending on the topic. It should be noted that there is considerable variation in the research literature with the implementation of both models.

In addition to an inquiry learning model this study will use a model of discovery learning to teach plane geometry (flat side). As a model of learning, discovery learning has similar principles with inquiry learning with discovery learning having more emphasis on the discovery of concepts or principles and less teacher intervention. Thus, the differences between discovery and inquiry can be seen in the problem statements given by the teacher. Inquiry learning problems are engineered by the teacher and given to the students while in discovery learning the problem is generated by the students with the teacher guiding them in the process. The learning activities are geared to empower all the potential of the students so that they can 
develop the competencies expected through efforts to grow and expand their attitudes, knowledge, and skills (Hosnan, 2014).

This study will examine the success of the application of an inquiry model of learning, a discovery learning model, or a classical model of mathematic learning for teachers to assist students to solve problems related to mathematics and build their understanding and skills especially in their writing on the concepts of geometry.

\section{Multiple Intelligences}

Another quality that is developed by the curriculum and should be realized in the learning process is the boosting of intelligence (multiple intelligences) of each students. Multiple intelligences of each individual play an important role in optimizing their potential and learning achievement. While there is only a small body of research evidence to support multiple intelligence, it has been widely embraced by teachers as a way of improving their strategies for dealing with the individual needs of students.

One type of intelligence is visual-spatial intelligence. According to Yaumi (2012) visual-spatial intelligence, or so-called spatial intelligence, is the ability to understand images and forms including the ability to interpret spatial dimensions that cannot be seen. Spatial intelligence is largely dependent on the ability to draw shapes, manipulate objects in imaginary space, and the ability to think spatially.

Related to spatial intelligence, research by Harmony and Theis (2012) stated that there is an interaction between learning outcomes of spatial intelligence and mathematics. Tambunan (2006) found that there is a relationship among the spatial total, topology and Euclidean mathematics learning achievement, but there is no relationship between the projective spatial intelligence and academic achievement in mathematics. Hoong and Khoh (2012) found that the level of spatial intelligence had a significant effect on mathematics achievement.

Achievement of learning and communication skills of students will be examined in the learning process with the application of classical learning, inquiry learning, and discovery learning with one of the multiple intelligences of the learner i.e., spatial intelligence. Therefore, researchers wanted to know the effect of inquiry learning and discovery learning in terms of spatial intelligence to learn and communicate mathematical achievement of students.

\section{Research Methods}

This is a quasi-experimental research design of factor $3 \times 3$. The study population was all students Grade 8 of junior high schools in Surakarta. The sampling used a stratified cluster random sampling technique. The sample for high school category was students Grade 8 of 
SMPN 7 Surakarta, SMPN 14 Surakarta for medium school category, and SMPN 20 Surakarta for lower school category.

The dependent variables in this study were the learning achievement and mathematical communication skills, while the independent variables were the models of learning and the spatial intelligence of the students. Data collection techniques used in this research were documentation and testing. The data was drawn from the final exam scores, odd semester of academic year 2014/2015. The tests were used to measure student learning achievement, mathematical communication skills, and spatial intelligence. The tests given after the treatment to measure student learning achievement used material such as cubes and blocks, while the tests to measure student mathematical communication skills were in the form of materials such as circle topic. For the spatial intelligence, multiple choice questions obtained from psychological tests and other sources were used as references.

Before the sample treatment, a test was analyzed using two-way multivariate analysis of variance and it was concluded that all three samples had the same initial capability or balance. Test instruments used in this research were subjected to prior validation of the content, internal consistency, distinguishing features, and reliability testing to determine the feasibility of the test items. To test the hypothesis of the study two-way multivariate analysis of variance (prerequisite test and post treatment test) was used, this included univariate and multivariate normality tests, homogeneity of variance, and variance covariance matrix equality tests. Hypothesis was followed by further analysis of two-way multivariate analysis of variance to determine the final conclusions followed by the multiple comparison test using Scheffe method.

\section{Treatment}

The three models were taught in the three schools selected and in each school three classes were randomly selected consisting of experiment class 1 with inquiry learning model, experiment class 2 with discovery learning model, and experiment class 3 with classical learning model. The total number of classes was nine. The problem used was building models in a flat space consisting of width and volume boundaries.

One teacher for each school used different models of inquiry, discovery, and classical in the classes. The instructions given to the teachers in each school were similar. The assumption is that every teacher in each school was expected to be able to apply the principles of inquiry, discovery, and classical learning in order to correctly measure students' abilities in applying these three models at the prescribed school level. This is a limitation of the study as there is no data to prove that the assumption is correct.

The teacher selected the problem to be solved by the students. The inquiry learning emphasized the process of searching and finding the material where the students are more 
directed towards finding and investigating a matter of being closely guided by the established scientific approach (SA). The SA is proposed by the Ministry of Education and Culture (MoEC) of the Republic of Indonesia and consists of five steps: (1) observing, (2) questioning, (3) collecting data, (4) reasoning, and (5) communicating. In addition, the inquiry learning emphasizes students formulating the problems, conducting experiments, and forming complex conclusions either individually or in groups (MoEC, 2014).

While applying the discovery learning students were given more freedom in accordance with their intuition in finding solutions to the problems given. Students could explore their ability to find answers to the questions given in accordance with their effort and imagination. They determined for themselves how the SA was used while still guided by good research principles.

During the inquiry learning, the teacher provided guidance to the students in the process of finding and selecting the material. This guidance was a comprehensive step in the process of finding and selecting material that was determined by the teacher. While in discovery learning, teachers gave freedom to students in finding and selecting material. Students were not given the specific steps by the teacher. Students had the authority in determining their own steps so in broad terms the teacher's contribution in discovery learning was less than in inquiry. Both of them have the teacher's contribution although they were different in magnitude. In our study both models used the MoEC's SA.

Classical learning means the teacher carries out two activities at once, namely classroom management and learning management. The teacher presents the information in a logical sequence for the students to learn. This is often termed 'transmission teaching' or 'teacher centered' teaching. In this research, while the teacher was implementing the classical learning, the SA was not used.

The implementation of learning model experiments and delivery of lesson material was conducted in each school in six meetings from February to April 2015. The time gap between the end of the treatment and the testing was one week.

\section{Results and Discussion}

Based on data from the study that included a prerequisite test and a post treatment test the results of univariate and multivariate normality tests concluded that the population approximated a normal distribution. The homogeneity of variance and variance covariance matrix equality test research data showed that the population had the same variance and a covariance matrix. A summary of two-way multivariate analysis of variance can be seen in Table 1. 
Based on Table 1, it can be concluded that: (1) there were differences in effects among the learning models for learning achievement and mathematical communication skills, (2) there were differences in effects between the spatial intelligence for learning achievement and mathematical communication skills; and (3) there was no interaction among the learning models and spatial intelligence for learning achievement and mathematical communication skills.

Table 1.

Summary of Two-way Multivariate Analysis of Variance

\begin{tabular}{|c|c|c|c|c|c|c|c|}
\hline Variation Source & Matrix SSCP & & $D k$ & $\Lambda$ & $F_{o b s}$ & $F_{\alpha}$ & Decision \\
\hline Factor A & $\boldsymbol{H}_{\boldsymbol{A}}=\left[\begin{array}{c}17588.43 \\
17270.1\end{array}\right.$ & $\left.\begin{array}{c}17270.1 \\
17771.28\end{array}\right]$ & 2 & 0.706 & 11.23 & 2.389 & $H_{0} \mathrm{~A}$ rejected \\
\hline Factor B & $\boldsymbol{H}_{\boldsymbol{B}}=\left[\begin{array}{l}7593.37 \\
7959.03\end{array}\right.$ & $\left.\begin{array}{l}7959.03 \\
8465.17\end{array}\right]$ & 2 & 0.851 & 23.46 & 2.389 & $H_{0} \mathrm{~B}$ rejected \\
\hline Interaction & $\boldsymbol{H}_{A B}=\left[\begin{array}{l}3895.20 \\
2733.87\end{array}\right.$ & $\left.\begin{array}{l}2733.87 \\
2230.51\end{array}\right]$ & 4 & 0.953 & 0.981 & 1.957 & $H_{0}$ accepted \\
\hline Error & $\boldsymbol{H}_{\boldsymbol{E}}=\left[\begin{array}{l}55715.66 \\
43534,71\end{array}\right.$ & $\left.\begin{array}{l}43534.71 \\
51907.83\end{array}\right]$ & 251 & - & - & - & - \\
\hline Total & $\boldsymbol{T}=\left[\begin{array}{l}84792.67 \\
71497.72\end{array}\right.$ & $\left.\begin{array}{l}71497.72 \\
80374.79\end{array}\right]$ & 260 & - & - & - & - \\
\hline
\end{tabular}

Table 1 shows that H_OA was rejected, H_OB was rejected, and H_OAB was accepted. Thus, each dependent variable learning achievement (X1) and mathematical communication skills (X2) with two-way multivariate analysis of variance need further testing. The summary of two-way univariate analysis of variance is presented in Table 2.

Table 2.

Summary of Two-way Univariate Analysis of Variance

\begin{tabular}{lccllll}
\hline Variation Source & Matrix SSCP & $D k$ & $\Lambda$ & $F_{o b s}$ & $F_{\alpha}$ & Decision \\
\hline Factor A & $\boldsymbol{H}_{\boldsymbol{A}}=\left[\begin{array}{ll}17588.43 & 17270.1 \\
17270.1 & 17771.28\end{array}\right]$ & 2 & 0.706 & 11.23 & 2.389 & $H_{0}$ A rejected \\
Factor B & $\boldsymbol{H}_{\boldsymbol{B}}=\left[\begin{array}{ll}7593.37 & 7959.03 \\
7959.03 & 8465.17\end{array}\right]$ & 2 & 0.851 & 23.46 & 2.389 & $H_{0}$ B rejected \\
Interaction & $\boldsymbol{H}_{\boldsymbol{A} \boldsymbol{B}}=\left[\begin{array}{ll}3895.20 & 2733.87 \\
2733.87 & 2230.51\end{array}\right]$ & 4 & 0.953 & 0.981 & 1.957 & $H_{0}$ accepted \\
Error & $\boldsymbol{H}_{\boldsymbol{E}}=\left[\begin{array}{ll}55715.66 & 43534,71 \\
43534.71 & 51907,83\end{array}\right]$ & 251 & - & - & - & - \\
Total & $\boldsymbol{T}=\left[\begin{array}{ll}84792.67 & 71497.72 \\
71497.72 & 80374.79\end{array}\right]$ & 260 & - & - & - & - \\
\hline
\end{tabular}

Based on the results of the two-way univariate analysis of variance it is known that the learning models and spatial intelligence on each dependent variable Fobs $>\mathrm{F} \alpha$, consequently F_obs $\in$ DK, so H0A and H0B rejected, while the interaction effect $\leq \mathrm{F} \alpha$ Fobs, consequently F_obs, so H0AB accepted DK. With a significance level of 5\% it can be concluded that: (1) there are differences in effects among the learning models for learning achievement and mathematical communication skills, (2) there are differences in effects between spatial intelligence of learning achievement and mathematical communication skills, and (3) there is no interaction between learning models and spatial intelligence for learning achievement and mathematical communication skills. 
Having obtained the results of two-way multivariate analysis of variance that HOA and $\mathrm{H} 0 \mathrm{~B}$ rejected, to know which treatment is significantly different from the other multiple comparison test was conducted on each dependent variable. In this study, the multiple comparison test used is the Scheffe method.

Table 3.

Average Data Research

\begin{tabular}{|c|c|c|c|c|c|}
\hline \multirow{2}{*}{\multicolumn{2}{|c|}{ Learning Models (Factor A) }} & \multicolumn{3}{|c|}{ Spatial Intelligence (Factor B) } & \multirow{2}{*}{$\begin{array}{l}\text { Average } \\
\text { Marginal } \\
\text { Low }\end{array}$} \\
\hline & & High & Medium & Low & \\
\hline \multirow{2}{*}{$\begin{array}{l}\text { Inquiry } \\
\text { Learning }\end{array}$} & Learning Achievement $\left(X_{1}\right)$ & 73,826 & 70,826 & 50 & 61,942 \\
\hline & Mathematical Communication Skills $\left(X_{2}\right)$ & 73,098 & 70,036 & 48,214 & 60,667 \\
\hline \multirow{2}{*}{$\begin{array}{l}\text { Discovery } \\
\text { Learning }\end{array}$} & Learning Achievement $\left(X_{1}\right)$ & 72,727 & 71,277 & 58,560 & 63,47 \\
\hline & Mathematical Communication Skills $\left(X_{2}\right)$ & 70,682 & 62,628 & 59,00 & 63,64 \\
\hline \multirow{2}{*}{$\begin{array}{l}\text { Classical } \\
\text { Learning }\end{array}$} & Learning Achievement $\left(X_{1}\right)$ & 63,900 & 69,820 & 45,920 & 51,707 \\
\hline & Mathematical Communication Skills $\left(X_{2}\right)$ & 57,875 & 61,644 & 42,45 & 49,048 \\
\hline \multirow{2}{*}{$\begin{array}{l}\text { Average } \\
\text { Marginal } \\
\text { Column }\end{array}$} & Learning Achievement $\left(X_{1}\right)$ & 71,151 & 70,477 & 51,490 & 64,372 \\
\hline & Mathematical Communication Skills $\left(X_{2}\right)$ & 66,30 & 65,020 & 50,580 & 60,633 \\
\hline
\end{tabular}

Table 4 presents a summary of the interlinear multiple comparison by Scheffe method on each of the dependent variables.

Table 4.

Summary of Interlinear Comparison Test

Dependent variable: learning achievement

\begin{tabular}{lllll}
\hline$H_{0}$ & & $F_{\text {obs }}$ & $(a-1) F_{\alpha}$ & Decision \\
\hline & $\mu_{11 .}=\mu_{12 .}$ & 0.307 & 6.064 & $H_{0}$ accepted \\
& $\mu_{11 .}=\mu_{13 .}$ & 13.945 & 6.064 & $H_{0}$ rejected \\
$\mu_{12 .}=\mu_{13 .}$ & 18.419 & 6.064 & $H_{0}$ rejected \\
\hline
\end{tabular}

Dependent variable: mathematical communication skills

\begin{tabular}{lllll}
\hline$H_{0}$ & & $F_{\text {obs }}$ & $(a-1) F_{\alpha}$ & Decision \\
\hline & $\mu_{21 .}=\mu_{22 .}$ & 2.048 & 6.064 & $H_{0}$ accepted \\
$\mu_{21 .}=\mu_{23 .}$ & 14.837 & 6.064 & $H_{0}$ rejected \\
$\mu_{22 .}=\mu_{23 .}$ & 27.998 & 6.064 & $H_{0}$ rejected \\
\hline
\end{tabular}

Based on Table 3 and Table 4, the following conclusions arose: (1) student learning achievement using inquiry learning and discovery learning was better than classical learning model, while student learning achievement using inquiry learning and discovery learning were similar and (2) student mathematical communication skills using inquiry learning and discovery learning were better than classical learning, meanwhile student mathematical communication skills using inquiry learning and discovery learning were the same.

A multiple comparison test between learning achievement and mathematical communication skills are presented in Table 5. 
Table 5.

Summary of Interlinear Comparison Mean

Dependent variable: learning achievement

\begin{tabular}{llll}
\hline$H_{0}$ & $F_{\text {obs }}$ & $(b-1) F_{\alpha}$ & Decision \\
\hline$\mu_{1.1}=\mu_{1.2}$ & 2,312 & 6,064 & $H_{0}$ accepted \\
$\mu_{1.1}=\mu_{1.3}$ & 42,23 & 6,064 & $H_{0}$ rejected \\
$\mu_{1.2}=\mu_{1.3}$ & 32,39 & 6,064 & $H_{0}$ rejected \\
\hline
\end{tabular}

Dependent variable: mathematical communication skills

\begin{tabular}{clll}
\hline$H_{0}$ & $F_{\text {obs }}$ & $(b-1) F_{\alpha}$ & Decision \\
\hline$\mu_{2.1}=\mu_{2.2}$ & 3,91 & 6,064 & $H_{0}$ accepted \\
$\mu_{2.1}=\mu_{2.3}$ & 27,25 & 6,064 & $H_{0}$ rejected \\
$\mu_{2.2}=\mu_{2.3}$ & 14,45 & 6,064 & $H_{0}$ rejected \\
\hline
\end{tabular}

Based on Table 3 and Table 5, the following conclusions arose: (1) learning achievement of students with high spatial intelligence was better than students with low spatial intelligence, while learning achievement of students with high spatial intelligence were similar; (2) mathematical communication skills of students with high spatial intelligence were better than students with low spatial intelligence, while mathematical communication skills of students with high spatial intelligence were similar.

There is a conformity between the hypotheses of the study and the researches which state that inquiry learning and discovery learning produce better learning achievement and mathematical communication skills than classical learning. It was impossible to separate the inquiry learning and discovery learning as learning achievement and mathematical communication skills were not different.

These above findings were influenced by the characteristics of inquiry learning and discovery learning that direct students to think critically, creatively, and innovatively in order to find new things related to the subject matter being studied. Using inquiry learning, students can construct their own knowledge (Kourilsky in Oemar, 2001). Discovery learning used in a constructivist approach aims to guide the students to have more active role in the learning process. Cranton (as cited in Devi, 2014) explains that in active learning, students are immersed in an experience where they are involved in the manufacture, investigation, action, imagination, discovery, interaction, hypotheses, and personal reflection.

This study, using a review of spatial intelligence, showed that learning achievement and mathematical communication skills of students with high spatial intelligence was better than those with low spatial intelligence. The results also showed the absence of the effect of among the learning models and spatial intelligence. By implementing inquiry learning, students who possessed high spatial intelligence acquired better learning achievement and mathematical communication skills than those with low spatial intelligence. The implementation of discovery 
learning also showed that students with high spatial intelligence had better learning achievements and mathematical communication skills than those with low spatial intelligence. On the other hand, using classical model and the other two learning models, students with high spatial intelligence produced similar results.

\section{Conclusions and Recommendations}

The conclusions of this study are: (1) using either inquiry learning or discovery learning produced better learning achievement and mathematical communication skills than using classical learning, (2) students with high spatial intelligence gained better learning achievement and mathematical communication than students who had low spatial intelligence, (3) inquiry learning, discovery learning, and classical all showed that students with high spatial intelligence had better mathematical communication skills than those with low spatial intelligence, and (4) students who with high, medium, or low spatial intelligence did better if they were taught using either inquiry learning or discovery learning rather than classical model.

Arising from this study teachers are encouraged to try and apply either inquiry learning or discovery learning to support students' creativity and improve their learning achievement. In addition, the researchers hope this study provides some guidance to other researchers to expand research on inquiry learning and discovery learning.

\section{References}

Dheeraj, D., \& Kumari, R. (2013). Effect of co-operative learning on achievement in environmental science of school student. International Journal of Scientific and Research Publications, 3(2), 1-3.

Devi, A. S. (2014). Active learning models for effective teaching. India: Jawaharlal Nehru Technological University Hyderabad.

Dona, D. P. (2013). Kemampuan komunikasi matematis dalam pemecahan masalah matematika sesuai dengan gaya kognitif pada siswa kelas IX SMP Negeri 1 Surakarta tahun pelajaran 2012/2013 (Master's thesis). Universitas Negeri Surakarta, Surakarta.

Hamalik, O. (2001). Proses belajar mengajar. Bandung : Bumi Aksara.

Hamzah, A., \& Muhlisrarini. (2014). Perencanaan dan strategi pembelajaran matematika. Jakarta: PT Raja Grafindo Persada.

Harmony, J., \& Theis, R. (2012). Pengaruh kemampuan spasial terhadap hasil belajar matematika siswa kelas VII SMP Negeri 9 Kota Jambi. Edumatica, 2(1), 11-19.

Hoong, L. Y., \& Khoh, L. S. (2012). Effects of geometer's sketchpad on spatial ability and achievement in transformation geometry among secondary two students in Singapore. National Institute of Education, Nanyang Technological University, Singapore. 
Hirschfeld, K. (2008). Mathematical communication, conceptual understanding, and student's attitudes toward mathematics (In partial fulfilment of the MAT Degree). University of Nebraska-Lincoln.

Hosnan, M. (2014). Pendekatan saintifik dan kontekstual dalam pembelajaran abad 21. Bogor: Ghalia Indonesia.

Kemendikbud. (2014). Implementasi kurikulum 2013. Jakarta: Kemendikbud.

NCTM. (2000). Principles and standards for school mathematics. Reston VA: NCTM.

Slameto. (2003). Belajar dan faktor-faktor yang mempengaruhinya. Jakarta: Rineka Cipta.

Tambunan, S. T. (2006). Hubungan antara kemampuan spasial dengan prestasi belajar matematika. Makara, Sosial Humaniora, 9(1), 27-32.

Yaumi, M. (2012). Pembelajaran berbasis multiple intelligences. Jakarta: PT Dian Rakyat. 

Southeast Asian Mathematics Education Journal 2017, Vol. 7 No. 2 